\title{
The use of the tetrazolium reduction test for the detection of the terminal electron transport system (ETS) activity in decomposing reed (Phragmites australis /Cav./ Trin. ex Steud.) rhizome
}

\author{
E. Szabó
}

Institute of Ecology and Botany, Hungarian Danube Research Station of the HAS, H-2163 Vacratot, Alkotmany street 2-4, Hungary. E-mail : edit@botanika.hu

\begin{abstract}
Tetrazolium reduction and enzyme kinetics were examined to estimate the ETS activity of decomposing reed (Phragmites australis /Cav./ Trin. ex Steud.) rhizome to collect information on the activity of microbial decomposers. Optimal incubation time was determined at $22{ }^{\circ} \mathrm{C}$. For complete enzyme extraction, 4-6 min. of homogenization was necessary. The main substrates of the enzymatic reaction were NADH and NADPH. The reaction was fastest when 2-(-p-iodophenyl)-3-(-p-nitrophenyl)-5-phenyl tetrazolium chloride (INT ; $0.8 \mathrm{mM})$, NADPH $(0.25 \mathrm{mM})$ and NADH $(1.7 \mathrm{mM})$ were applied simultaneously. The optimal incubation time should be less than 20 minutes. The $\mathrm{pH}$ optimum of the enzyme reaction is 8.0-8.4. ETS activity of decomposing reed rhizome can be used to estimate potentially the oxygen consumption of microorganisms involved in decomposition and, indirectly, the rate of decomposition.
\end{abstract}

Keywords : electron transport system, enzyme activity, reed rhizome, decomposition, tetrazolium test.

\section{Introduction}

In wetland ecosystems a considerable part of the organic material production is formed by emergent macrophytes (Wetzel 1990, Gessner et al. 1996), which play an important part in the detritus food chain (Wetzel 1981). Their decomposition has a significant influence on the structural and functional aspects of wetlands because the nutrients stored by them find their way back to the aquatic ecosystem during their decomposition. The direction of the decomposition is determined by two factors, the initial composition of the plant detritus and the activity of the microbial decomposer community (bacteria, fungi, etc.). Bacteria and fungi dominate decomposition of organic material (Saunders et al. 1980). They produce enzymes that can break down macromolecular organic material into smaller, more easily digestible molecules (Sinsabaugh \& Linkins 1990).

The terminal electron transport system (ETS) is situated in the cell membrane in bacteria and in the inner mitochondrial membrane in eucaryotes. It transfers electrons from the coenzymes produced by the Szent-
Györgyi \& Krebs cycle (NADH, NADPH, Na-succinate) to the terminal electron acceptor. Using an enzymatic approach, Packard (1971) suggested that respiration should be closely related to the activity of the respiratory electron transport system (ETS). Kenner \& Ahmed (1975), Christiansen et al. (1980) demonstrated that a first order relationship exists between ETSactivity and respiratory capacity in aquatic microorganisms.

The ETS test is based on the reduction of 2-(-p-iodophenyl)-3-(-p-nitrophenyl)-5-phenyl tetrazolium chloride (INT), which, acting as an artificial electron acceptor, connects to the electron transport chain between the ubichinon and the cytochrome-b complex before the natural electron acceptor, and transforms into red formazan. There are two main spectrophotometric methods used to measure ETS-activity, both are based on the reduction of INT, the main difference between the two methods is, that in one of the cases the in vitro dehydrogenase activity of microorganisms is measured, cell free extracts are incubated in a reaction mixture containing ETS stimulators (NADH, NADPH) and INT solution in surplus and in the other case, 
viable microorganisms are incubated with INT for maintaining the electron flow in the respiratory chain, which indicates the in vivo ETS-activity because the result reflect the apparent level of the intracellular substrates, supposing that the INT uptake of the microorganisms does not limit the reaction. Although the statistical correlation between the in vivo measured ETSactivity and the direct measured oxygen consumption exists (Trevors 1984), the ETS-activity is not equivalent with the directly measurable $\mathrm{O}_{2}$ consumption because the INT interfere with the cell biochemistry (Antonietti 1998). Nevertheless, this version of the ETS is widely used for sediments, soils and biofilms (Trevors 1984, Mulholland et al. 1984, Blekinsopp \& Lock 1990, Maamri et al. 1999). The advantage of the in vitro measured microbial ETS-activity is that the method is well standardized by an enzyme extraction step and the saturation of the reaction rate adding electron donors (NADH, NADPH). The assay estimates the rate of respiration when neither substrates nor acceptor of electrons limit the reactions. The electron flow in the respiratory chain is maintained by the input of substrate (NADH and NADPH) and the result is considered as a measure of the maximum activity of the enzyme. The reaction product produced during the process can be determined spectrophotometrically at a wavelength of $490 \mathrm{~nm}$ and is closely correlated with oxygen consumption of the investigated organisms.

Studies of the relationship between in vitro measured ETS-activity and oxygen consumption (R) have shown that ETS-activity can predict the respiration rate of zooplankton, phytoplankton (Kenner \& Ahmed, 1975, Owens \& King 1975, Devol \& Packard 1978, Packard 1985), sediments (Broberg 1985) and bacteria (Christensen et al. 1980). The in vitro measured ETS activity of decomposing reed rhizome is a measure of the potential microbial activity. However, the microbial activity is also influenced by the availability of nutrients (Burton \& Lanza 1986) and correlates with the decomposition rate of organic material as well (Maamri et al. 1999). The ETS activity of decomposing reed rhizome is considered as a global activity parameter because we are not able to distinguish to what extent the activities of the different individual components (bacteria, fungi, protozoa, algae) in the microbial community contribute to total ETS activity.

The ETS test developed by Packard (1971), Kenner \& Ahmed (1975), Owens \& King (1975), and Broberg (1985), which is widely used to measure in vitro dehydrogenase activity of organisms, was applied with enzyme kinetic experiments on the decomposing reed rhizome. The aim of this work was to develop a quick and easy method to determine the microbial activity and the potential oxygen consumption of microbial decomposers so as to evaluate the relative contributions of microorganisms to litter breakdown, additional studies were also conducted to examine the seasonal changes in microbial activity and the effect of temperature on potential respiratory activity during the decomposition of the reed rhizome.

\section{Materials and methods}

The ETS-assay described by Kenner \& Ahmed (1975) and Owens \& King (1975) has been taken as the standard method.The optimal measuring conditions of the ETS activity of the decomposing reed rhizome were determined with the help of enzyme kinetic experiments, which is necessary for the correct estimation of the potential microbial electron transport activity. If the enzyme preparation or the assay conditions are less than the optimum the ETS measurement will underestimate the respiratory capacity of the microorganisms.

We first determined the optimal enzyme preparation procedure (homogenization technique and time, separation of the ETS fractions), the optimal incubation time, the saturating levels of the reagent, INT and the substrates NADH, NADPH.

After determining the wet weight of decomposing reed rhizome, it was homogenized with a potter homogenator $\left(5000 \mathrm{rpm}, 0-4{ }^{\circ} \mathrm{C}\right.$, B. Braun Biotech. International) in $10-15 \mathrm{~cm}^{3}$ of a homogenizing mixture, consisting of $\mathrm{MgSO}_{4}(75 \mu \mathrm{M})$, Triton-X-100 $0.5 \%$ (v/v), polyvinyl pyrolidone (PVP) $1.5 \% \mathrm{w} / \mathrm{v}$, in $0.1 \mathrm{M}$ phosphate buffer ( $\mathrm{pH}$ 8.4). We used decomposing reed rhizome (180-days-old) in these experiments at concentration of about $5 \mathrm{mg}$ wet weight decomposing reed rhizome per $\mathrm{ml}$ of homogenate. Samples were homogenized for $2,4,6,8$, and 10 minutes, respectively in order to determine the optimal homogenization time.

The effect of ultrasonic treatment (Labsonic L. B. Braun) on ETS activity was checked at $0-4{ }^{\circ} \mathrm{C}$ and the effect of centrifugation (Medifuge Heraeus, $5000 \mathrm{~g}, 2$, $4,6,8,10$ minutes, $0{ }^{\circ} \mathrm{C}$ ), the optimal composition of the substrate mixture (NADH, NADPH, Na succinate) and the optimal quantity of the INT reagent were checked at $22{ }^{\circ} \mathrm{C}$. There was no more than $10-15$ minutes between the preparation of the homogenate and the start of the reaction. Samples were stored at $0-4{ }^{\circ} \mathrm{C}$ until the beginning of the incubation.

During the kinetic experiments the same aliquot of the homogenate was always incubated in the series of substrate solutions, which contained either NADH, $\mathrm{NADPH}$, or Na succinate at different concentrations 
and had the same INT concentration $(0.8 \mathrm{mM})$ and $\mathrm{pH}$ (8.4).

When applying the substrates simultaneously, one was always used in excess and the concentration of the other one was changed. With constant NADH concentration $(1.7 \mathrm{mM})$ the NADPH concentration $(0.015-$ $0.5 \mathrm{mM}$ ) was changed and vica versa, with constant NADPH concentration $(0.25 \mathrm{mM})$ the NADH concentration (0.1-3.4 mM) was changed.

Having set the other parameters to their optimal values, we examined the $\mathrm{pH}$ optimum of the reaction between 4.5 and 9.0. The optimal incubation time was defined at $22{ }^{\circ} \mathrm{C}, 0.5 \mathrm{~cm}^{3}$ of the homogenate was incubated with $0.5 \mathrm{~cm}^{3}$ INT reagent in three parallel $1.5 \mathrm{~cm}^{3}$ substrate mixtures. The reaction was stopped after $5,10,20,40,80$, and 160 minutes with a $0.5 \mathrm{~cm}^{3}$, $1: 1$ mixture of concentrated phosphoric acid and formalin. Within ten minutes after stopping the reaction, the absorbance of the formazan produced during the reaction was determined against the blind probe at a wavelenght of $490 \mathrm{~nm}$ (Spektronom 195 D photometer). The blank sample contained $1.5 \mathrm{~cm}^{3}$ substrate solution and $0.5 \mathrm{~cm}^{3}$ INT reagent and it was incubated for the same length of time as the sample but the $0.5 \mathrm{~cm}^{3}$ homogenate was added to it only after the reaction was stopped. The residual ETS activity was determined after sterilization of the rhizome samples with autoclave $\left(221 \mathrm{kPa}, 120^{\circ} \mathrm{C}, 20\right.$ minutes $)$.

The respiratory ETS-activity at different stage of decomposition was determined after adaptation of the method to decomposing reed rhizome. Decomposition of Phragmites australis (Cav. Trin ex Steudel) rhizome was studied at Lake Fertó/ Neusiedler See using a litter bag technique. Healthy, intact rhizomes were collected for decomposition studies at the site of reed damage caused by harvesting machines, wet rhizome pieces were put into the nylon litter bags and placed out at $30 \mathrm{~cm}$ above the sediment at a die-back reed stand area of Lake Fertó/Neusiedler See, on $9^{\text {th }}$ March 1999. Litter bags were periodically retrieved for determination of the dry mass at $105^{\circ} \mathrm{C}$ and of the ETS-activity. The ETS activity measured in the laboratory $\left(\right.$ ETS $\left._{\text {inc }}\right)$ was adjusted to ambient lake temperature using the Arrhenius equation:

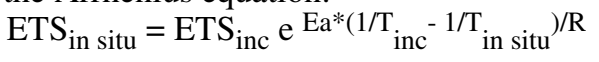

(Packard et al. 1971, Owens \& King 1975), where $\mathrm{E}_{\mathrm{a}}$ is the energy of activation, $\mathrm{T}_{\text {inc }}$ the incubation temperature expressed in Kelvin, $\mathrm{T}_{\text {in situ }}$ the ambient lake water temperature $\left({ }^{\circ} \mathrm{K}\right)$ and $\mathrm{R}$ is a gas constant $(1.987$ cal $\mathrm{mol}^{-1} \mathrm{~K}^{-1}$ ). The value of $\mathrm{E}_{\mathrm{a}}$ has been calculated by constructing an Arrhenius plot of log ETS-activity against $1 / \mathrm{T}$, where $\mathrm{T}$ is the absolute temperature ex- pressed in Kelvin), the value obtained was $16.88 \mathrm{kcal}$ $\mathrm{mol}^{-1}{ }^{\circ} \mathrm{K}^{-1}$.

\section{Results}

Homogenization of 20-40 mg decomposing reed rhizome for 4-6 minutes (potter homogenizer, 0-4 ${ }^{\circ} \mathrm{C}$, $5000 \mathrm{rpm}$ ) proved to be enough for the maximum extraction of the ETS. Homogenization time exceeding 8 minutes reduced ETS activity. In further measurements samples were homogenized for 4 minutes. The ETS activity of the centrifuged homogenate was lower than that of the non-centrifuged homogenate probably due to the higher turbidity caused by plant fibres (Figure 1). Centrifugation eliminated this effect. The ultrasonic treatment did not have a considerable influence on the ETS activity this step was therefore deleted. However, a 20-30 second ultrasonic treatment can be applied in the procedure. The produced formazan (which is proportional to ETS activity), plotted against time, showed a saturation curve. It grew gradually at first, then after 20 minutes of incubation the slope of the curve decreased, thus defining the optimal incubation time less than 20 minutes (Figure 2). ETS activity also exhibited a saturation curve when plotted against concentration of the INT solution. Formazan production stabilized over $0.8 \mathrm{mM}$ INT concentration (Figure 3 ).

The dependence of the INT reduction substrate was the following :

When the reaction mixture contained only NADH (Figure 5) or only NADPH (Figure 4), lower ETS activity values were recorded than when the two substrates were applied simultaneously (Figure 4, 5). The addition of $\mathrm{Na}$ succinate inhibited the reaction, and was therefore deleted from the reaction mixture (Table 1). The reaction rate was fastest when $0.25 \mathrm{mM}$ NADPH and $1.7 \mathrm{mM}$ NADH concentrations were applied simultaneously.

Table 1. Substrate dependence of the ETS activity (mean \pm $\mathrm{SE}, \mathrm{n}=3$ ).

\begin{tabular}{lll}
\hline Substrate (mM) & ETS (\%) & SE \\
\hline NADH (1.70) & 93.6 & 0.10 \\
NADPH (0.25) & 80.8 & 0.20 \\
Succinate (80) & 34.0 & 0.00 \\
NADH (1.70)+NADPH (0.25) & 100 & 0.07 \\
NADH (1.70)+Succinate (80) & 89.3 & 0.14 \\
NADPH (0.25)+Succinate (80) & 62.4 & 0.29 \\
NADH (1.70)+NADPH (0.25)+ & & \\
Succinate (80) & 91.5 & 0.07 \\
\hline
\end{tabular}




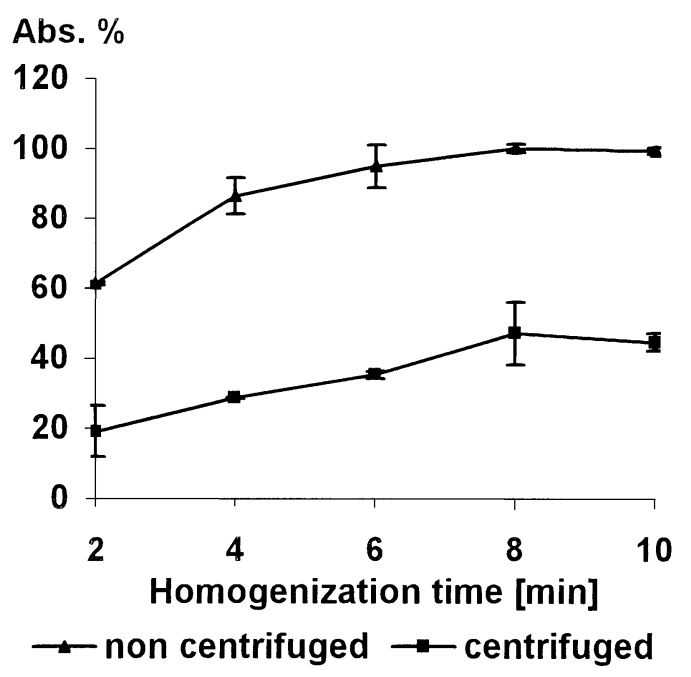

Fig. 1. Effect of the homogenization time on ETS activity of centrifuged and non-centrifuged samples (mean \pm $\mathrm{SE}$ : standard error, $\mathrm{n}=3$ ).

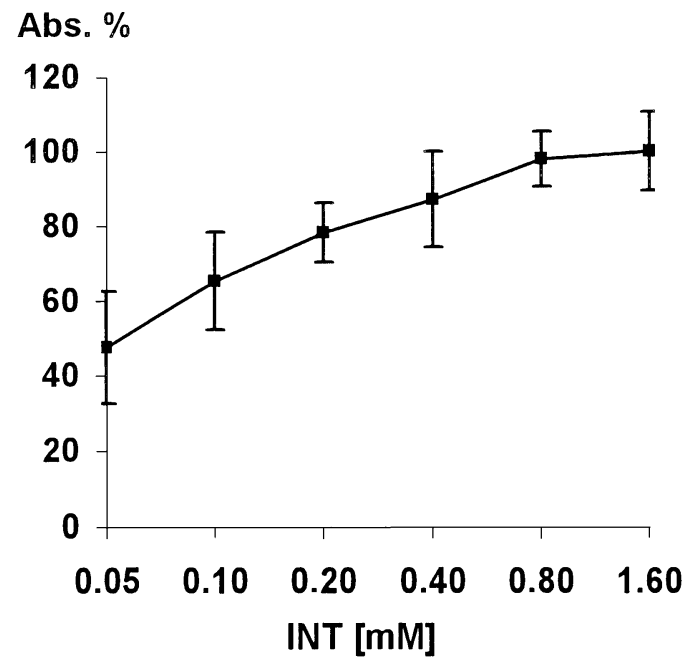

Fig. 3. Effect of INT concentration on the ETS activity (mean $\pm \mathrm{SE}, \mathrm{n}=3$ ).

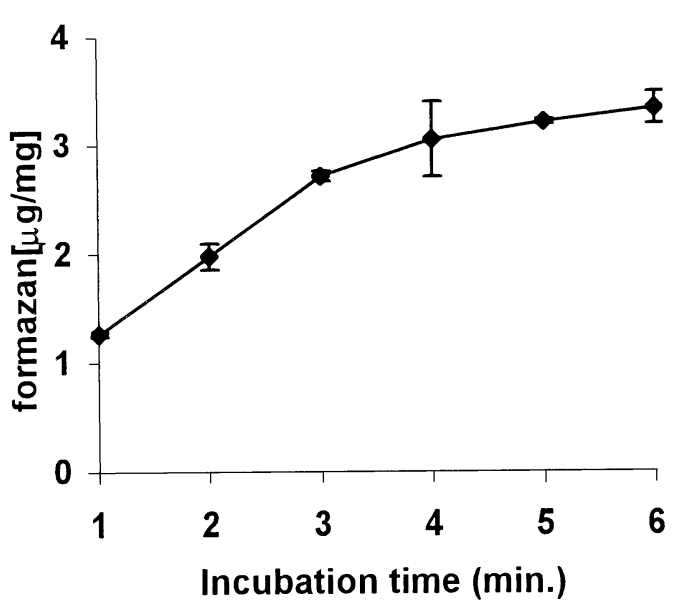

Fig. 2. Effect of incubation time on ETS activity (mean \pm $\mathrm{SE}, \mathrm{n}=3$ )

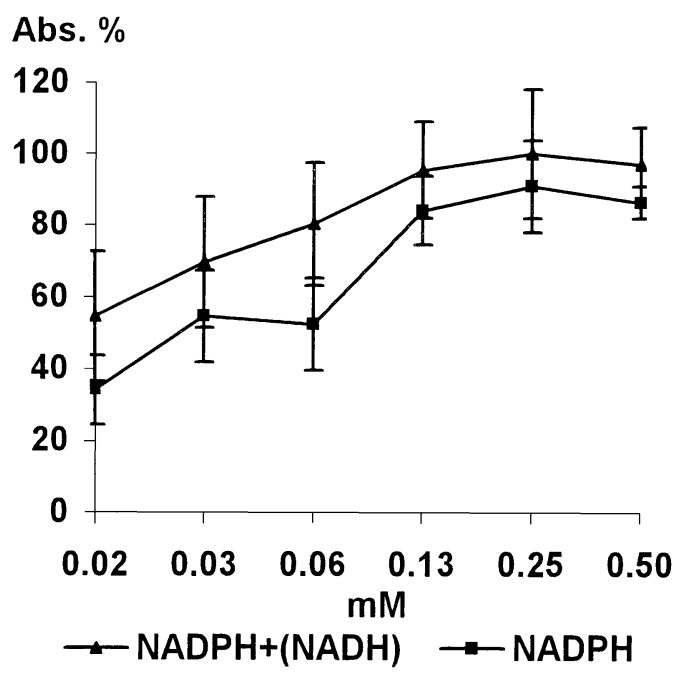

Fig. 4. Effect of substrate composition in reaction mixture on ETS activity using constant NADH and different NADPH concentrations (saturation concentrations in brackets) (mean $\pm \mathrm{SE}, \mathrm{n}=3$ ). 


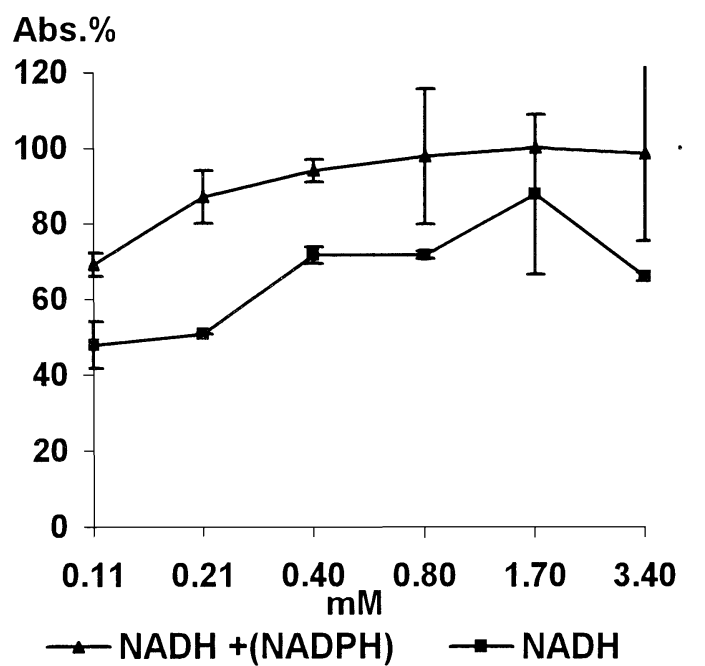

Fig. 5. Effect of substrate composition in reaction mixture on ETS activity using constant NADPH and different NADH concentrations (saturation concentrations in brackets) (mean $\pm \mathrm{SE}, \mathrm{n}=3$ ).
Abs. $\%$

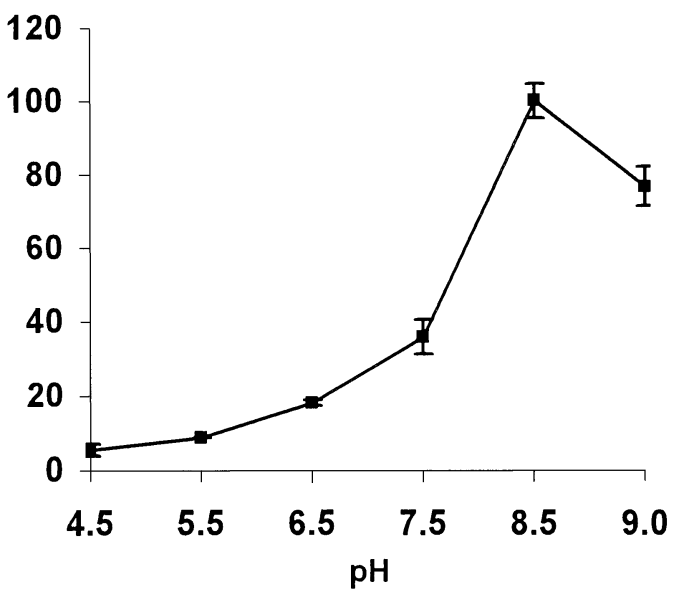

Fig. 6. Effect of $\mathrm{pH}$ of reaction mixture on ETS activity $($ mean $\pm \mathrm{SE}, \mathrm{n}=3$ ).

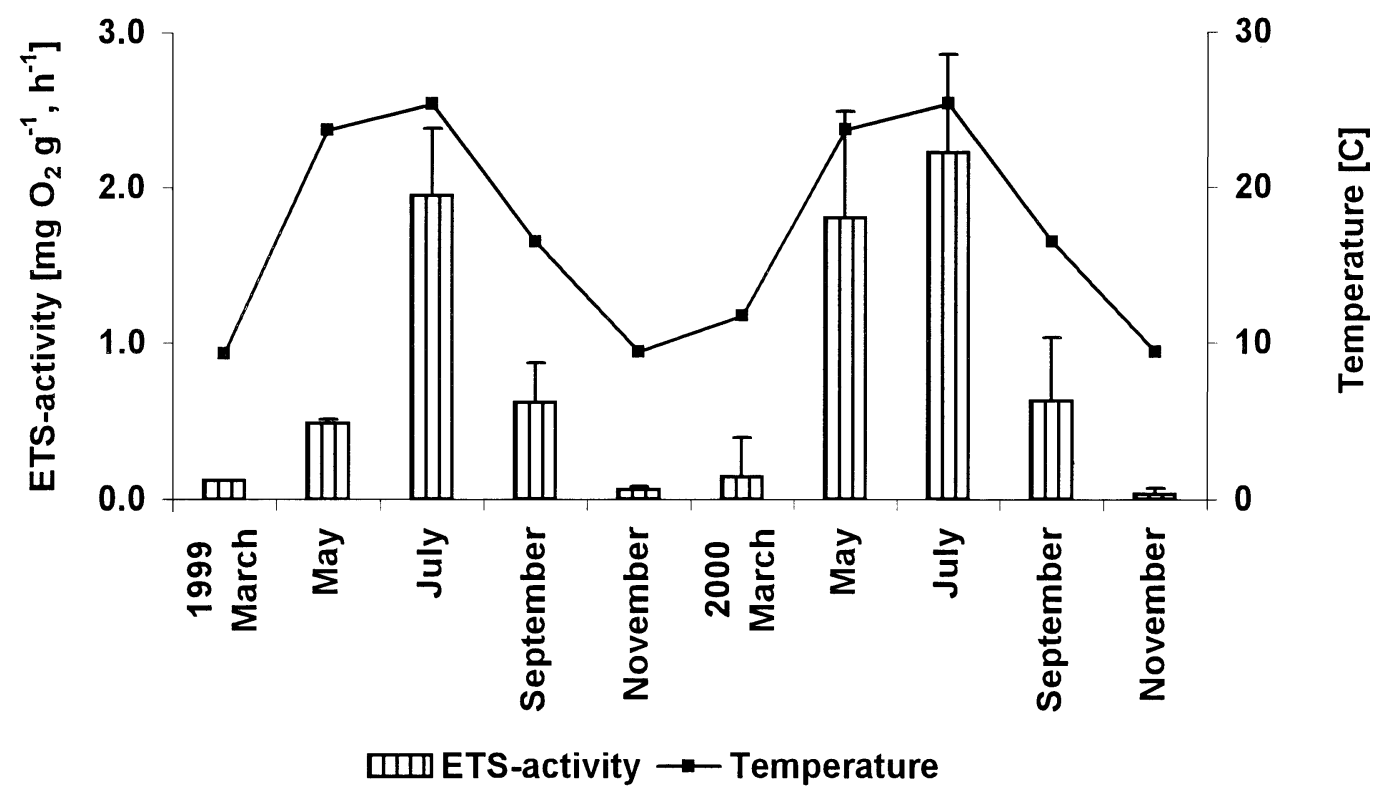

Fig. 7. ETS-activity during the breakdown of Phragmites australis rhizome (mean $\pm \mathrm{SE}, \mathrm{n}=3$ ). 
The $\mathrm{pH}$ strongly influenced the reaction rate (Figure 6 ), the $\mathrm{pH}$ optimum of the enzyme reaction was determined to be between 8.0-8.4. The ETS-activity of sterilized rhizome was $12.76 \pm 2.76 \%$ of the original ETS-activity. The ETS-activity of decomposing reed rhizome showed a seasonal trend during the 597 days of decomposition period and ranged from $0.03 \mathrm{mg} \mathrm{O}_{2}$ $\mathrm{g}^{-1}$ dry mass $\mathrm{h}^{-1}$ in November to $2.22 \mathrm{mg} \mathrm{O}_{2} \mathrm{~g}^{-1}$ dry mass $\mathrm{h}^{-1}$ in July (Figure 7). A strong relationship between the ETS-activity and temperature was observed, the changes in the pattern of potential oxygen uptake varied almost in parallel with the in situ temperature of the lake water. The microbial ETS-activity was maximum in July in each year. The temperature dependence of the ETS-activity is well described by the expression ETS $=0.196 \mathrm{e}^{0.0768 \mathrm{~T}}\left(\mathrm{r}^{2}=0.87\right)$, where ETS is the specific ETS-activity in $\mathrm{mg} \mathrm{O}_{2} \mathrm{~g}^{-1}$ dry mass $\mathrm{h}^{-1}$ and $\mathrm{T}$ is the temperature expressed in ${ }^{\circ} \mathrm{C}$. The exponential term is equivalent to a $\mathrm{Q}_{10}$ of 2.15 .

\section{Discussion}

In this study we determined the optimal measuring conditions of the ETS-activity of decomposing reed rhizome and we investigated the seasonal changes in the microbial activity during the decomposition. According to our results, the substrates, which were applied one by one, passed down their electrons to the respiratory chain with different intensity in the following order: NADH, NADPH, Na succinate. When Na succinate was applied together with other substrates, the activity values were lower than when it was not included in the reaction mixture (see Table 1). The simultaneous application of the substrates was not additive in any combination. The microbial communities participating in reed rhizome decomposition contain both eucaryotic (fungi) and procaryotic (bacteria) organisms (Kuehn et al. 1999), which have different electron transport systems (Packard 1971). Under certain circumstances, the respiratory chain of the procaryonts can change even in cells of the same species. The main substrate of the eucaryotic type electron transport chain is NADH. NADPH can pass down electrons either directly or indirectly to such chains (it can reduce $\mathrm{NAD}^{+}$in the presence of active dehydrogenase to NADH). Unlike this system, where NADPH can be a main electron donor in procarytes (eg. in Pseudomonas perfectomarinus, Packard (1985). This is the reason why almost identical absorbance values was recorded when only NADH or NADPH was applied.
We compared our results with ETS-activity measurements in other organisms. A longer homogenization time (4-6 minutes) is necessary to get a cell free enzyme extract from decomposing reed rhizome than from zooplankton, fish spawn (2-3 minutes), and the phytoplankton (3-4 minutes). Phytoplankton and the sediment require a further 20-30-second and a 4-20-minute ultrasonic treatment, respectively (Broberg 1985, G.-Tóth 1993). G.-Tóth (1999) also recommends ultrasonic treatment for the cell free enzyme extraction of heterotrophic nanoflagellata and bacterial colonies. Urbanc-Bercic (1977) produced a cell free homogenate from reed root after a 3-4 minutes potter homogenization and a 20-30 second ultra sound treatment as a next step the samples were centrifugated (10000 rpm) for 4 minutes, which were applied without previous enzyme kinetic experiments. The optimal substrate concentrations in our experiments were similar to those applied by Owens \& King (1975) and Packard (1985). Incubation periods of minutes to days for the ETS activity have been reported in previous studies. Our results suggest that the incubation time should be less than 20 minutes. A similar incubation time (20 minutes) has also been shown for the in vitro measured ETS activity of sediment, phyto- and zooplankton (Packard et al. 1971, Owens \& King 1975, Kenner \& Ahmed 1975, Broberg 1985). However under the low temperature conditions it may be necessary to incubate samples longer until measurable INT-formazan formation occurs. (Blenkinsopp \& Lock 1990). Burton \& Lanza (1986) suggested that it is advantageous to restrict the incubation period to a minimum because extended incubation results in decreased rates of formazan production and promotes changes in microbial community. The $\mathrm{pH}$ optimum of the examined reaction was 8.0-8.4, which is similar to the $\mathrm{pH}$ optimum given for zooplankton organisms (Owens \& King 1975, Kenner \& Ahmed 1975, G.-Tóth \& Zlinszky 1989), lake sediment (Broberg 1985, G.-Tóth 1993), and river biofilm (Blekinsopp \& Lock 1990). Since the ETS activity is $\mathrm{pH}$ dependent, $\mathrm{pH}$ influences the decomposition rate and the nutrient cycle. In alkaline lakes $(\mathrm{pH}>8)$ the decomposition rate may be twelve times higher than in extremely acidic $(\mathrm{pH}<4)$ waters $(\mathrm{G}$.Tóth \& Zlinszky 1989). The existing postmortem enzymatic activity suggest that ETS fractions can survive after the death of the cells and may increase the enzymatic activities. Bamstedt (1980), G.-Tóth \& Zlinszky (1989) also demonstrated that ETS-activity of dead planktonic crustaceans and algae may remain active for days after death. The role of postmortem enzymatic activity in the mineralization of the dead plant material need further studies. 
Results from field studies suggest a strong relationship between ETS-activity and temperature, the changes in the pattern of potential oxygen uptake varied almost in parallel with the in situ temperature of the lake water as also reported by Andersen (1978), and Barik et al. (2000). The increasing ETS activity between spring and summer reflected an enormous decomposition process (Dinka \& Szabó 2002) and microbial activity in the dead reed rhizome during the summer season.

The temperature is an important influencing factor of the decomposition (Hietz 1992), whereas the activity of the organisms involved in decomposition is temperature dependent (Harrison 1977).

The $\mathrm{Q}_{10}$ value of 2.15 is similar with the $\mathrm{Q}_{10}$ reported by Kuehn et al. (1999) and Kuehn \& Suberkropp (1998) for microbial assemblages associated with standing litter of Erianthus giganteus $\left(\mathrm{Q}_{10}=2.56\right)$ and Juncus effusus $\left(\mathrm{Q}_{10}=1.95\right)$, respectively. Comparing our results with other studies (Mulholland et al. 1984, Maamri et al. 1999) where the ETS-activity had been applied to plant material decomposing in aquatic environments, we found that the variation of the ETS activity during the decomposition period had a similar tendency. The initial increase in the ETS-activity reflects the microbial colonization process on the decomposing plant material. The seasonal changes in the microbial oxygen consumption of the decomposing reed rhizome and of the decomposing leaf material (Maamri et al. 1999) were also similar, but we measured 2.5-3.0 times higher activity values, which was due to the differences in the methodology used. This differences can be explained by the fact that the potential oxygen consumption expressed as the ETS-activity (when there is no substrate and electron acceptor limitation) is 2.6-3.0 times higher than the real oxygen consumption determined by titrimetric version of the Winkler oxygen method (Szabó, unpublished data).

The in vitro ETS assay, which is well standardized by the enzyme extraction step and it yields the respiratory capacity of the microorganisms, which is normally higher than the normal respiration rate, but from the relationship (ETS/R) between ETS activity and respiration $(\mathrm{R})$, which is constant for a specific group of organisms, the respiratory oxygen consumption (R) can be calculated (Packard 1985, Kenner \& Ahmed 1975, Owens \& King 1975, Devol \& Packard 1978, Christensen et al. 1980, Broberg 1985, G.-Tóth et al. 1994, G.-Tóth \& Drits 1991, Muskó et al. 1995, Muskó et al.1998 etc.).

The ETS method is sensitive, specific, simple, easily standardised and relatively fast. The ETS activity of the decomposing reed rhizome can be an indicator of microbial organisms participating in the decomposition, if we disregard their physiological status and growth conditions.

This paper presented the first adaptation of the tetrazolium reduction test for measuring the in vitro ETSactivity of decomposing plant material. Our results are in accordance with the standard ETS test applied for plankton (Packard 1971, Kenner \& Ahmed 1975, Owens \& King 1975). From the speed of tetrazolium reduction the potential oxygen consumption of the reed rhizome, the ETS function and activity of decomposing organisms can be estimated.

\section{Acknowledgements}

M.O. Gessner, F. Bärlocher, M. Zimmer, M. Dinka provided many valuable, helpful suggestions for which I am grateful. I am also thankful for two anonymous reviewers who offered constructive suggestions. This work was financially supported by AKP and $\mathrm{OKT}(\mathrm{KP})$.

\section{References}

Andersen F.O. 1978. - Effects of nutrient level on the decomposition of Phragmites communis Trin. Arch. Hydrobiol., 84 : 42-54.

Antonietti R. 1998. — Effects of Electron Transport System (E.T.S.) activity measurements on the ATP pool in microorganisms. Verh. Int. Verein. Limnol., 26 : 1605-1607.

Bamstedt U. 1980. — ETS activity as an estimator of respiratory rate of zooplankton populations. The significance of variations in environmental factors. J. exp. Biol. Ecol., 42 : 267-283.

Barik S.K., Mishra S. \& Ayyappan S. 2000. — Decomposition patterns of unprocessed and processed lignocellulosics in a freshwater fish pond. Aquat. Ecol., 34 : 185-204.

Blenkinsopp S.A. \& Lock M.A. 1990. - The measurement of electron transport system activity in river biofilms. Wat. Res., 24 : 441-445.

Broberg A. 1985. - A modified method for studies of electron transport system activity in freshwater sediments. Hydrobiologia, $120: 181-187$.

Burton G.A. Jr. \& Lanza G.R. 1986. - Variables Affecting Two Electron Transport System Assays. Appl. Environ. Microbiol., $51: 931-937$.

Christensen J.P., Owens T.G., Devol, A.H. \& Packard T.T. 1980. Respiration and Physiological State in Marine Bacteria. Mar. Biol., 55 : 267-276.

Devol A.H. \& Packard T.T. 1978. — Seasonal changes in respiratory enzyme activity and productivity in Lake Washington microplankton. Limnol. Oceanogr., 23 : 104-111.

Dinka M. \& Szabó E. 2002. - In situ decomposition of different reed organs (in Hungarian : A nád kûlönbözo szerveinek in situ dekompozíciója, with an English abstract). Hidrol. Közl., 82 : 24-27.

G.-Tóth L., Langó Zs., Padisák J. \& Varga E. 1994. — Terminal electron transport system (ETS) activity in the sediment of Lake Balaton, Hungary. Hydrobiologia, 281 : 129-139. 
G.-Tóth L. \& Zlinszky J. 1989. - The importance of self oxidation in decomposition and its dependence of the $\mathrm{pH}$ of the environment. Water, Air and Soil Pollution ,46 : 213-219.

G.-Tóth L. 1993. Electron transport system activity of the plankton, sediment and biofilm in Lake Balaton (Hungary). Verh. Internat. Verein. Limnol., 25 : 680 - 681.

G.-Tóth L. 1999. - Aktivitat des Electrontransportsystems (ETS). Pages 465-473 in Methoden der Biologischen Wasseruntersuchung 2. W.v. Tûmpling (Ed.). Biologische Gewasserunterschung. Gustav Fisher Verlag.

G.-Tóth L. \& Drits A.V. 1991. - Respiratory energy loss of zooplankton in Lake Balaton (Hungary) estimated by ETS-activity measurements. Verh. Internat. Verein. Limnol., 24 : 993-996.

Gessner M.O., Schieferstein B., Müller U., Barkmann S., \& Lenfers U. A. 1996. - A partial budget of primary organic carbon flows in the littoral zone of hardwater lake. Aquat. Bot., 55 : 93-105.

Harrison P.G. 1977. — Decomposition of macrophyte detritus in seawater : effects of grazing by amphypods. Oikos, $28: 165-169$.

Heitz P. 1992. — Decomposition and nutrient dynamics of reed (Phragmites australis (Cav.) Trin ex.Steud) litter in Lake Neusiedl, Austria. Aquat. Bot., 43 : 211-230.

Kenner R.A. \& Ahmed S.I. 1975. - Measurement of electron transport system activities in marine phytoplankton. Mar. Biol., 33 : 119-127.

Kuehn K.A., Gessner M.O., Wetzel R.G., \& Suberkropp K. 1999. Decomposition and $\mathrm{CO}_{2}$ evolution from standing litter of the emergent macrophyte Erianthus giganteus. Microb. Ecol., 38 : 50-57.

Kuehn K.A. \& Suberkropp K. 1998. — Decomposition of standing leaf litter of the freshwater emergent macrophyte Juncus effusus. Freshwat. Biol., 40 : 217-227.

Maamri A., Pattee E., Gayte X. \& Chergui H. 1999. — Microbial dynamics on decaying leaves in a temporary Moroccan river IIBacteria. Arch. Hydrobiol., 144 : 157-175.

Mulholland P.J., Elwood J.W., Newbold J.D., Webster J.R., Ferren L.A. \& Perkins R.E. 1984. — Phosphorus uptake by decomposing leaf detritus : Effect of microbial biomass and activity. Verh. Internat. Verein. Limnol., 22 : 1899-1905.
Muskó I.B., G.-Tóth L. \& Szabó E. 1995. — Respiration and respiratory electron transport system (ETS-activity) of two amphipods : Corophium curvispinum G. O. Sars and Gammarus fossarum Koch. Pol. Arch. Hydrobiol., 42 : 547-558.

Muskó I.B., G.-Tóth L. \& Szabó E. 1998. — Respiratory energy loss of Corophium curvispinum (Crustacea : Amphipoda) in Lake Balaton (Hungary) during the vegetation period. Verh. Internat. Verein. Limnol., 26 : 2107-2114.

Owens T.G. \& King F.D. 1975. - The measurement of respiratory electron transport system activity in marine zooplankton. Mar. Biol., $30: 27-36$.

Packard T.T. \& Healy M.L. \& Richards F.A. 1971. — A vertical distribution of the activity of the respirarory electron transport system in marine plankton. Limnol. Oceanogr., $16 / 1: 60-70$.

Packard T.T. 1971. - The measurement of respiratory electron transport activity in marine phytoplankton. Journal of Marine Research, $29: 235-244$.

Packard T.T. 1985. - Measurement of electron transport activity of microplankton. Pages 207-261 in Advances in aquatic microbiology 3. Janash H. \& Williams P.J. Leb. (Eds). Academic Press London.

Saunders G.W., Cummins K.W., Gak K.Z., Pieczynska E., Straskrabova V. \& Wetzel R.G. 1980. — Organic matter decomposition. Pages 341-392 in The funcionary of freshwater ecosystems. Le Cren E.D. \& Mc Connel R.M.L. (Eds.). Cambridge.

Sinsabaugh R.L. \& Linkins A.E. 1990. - Enzymatic and chemical analysis of particulate organic matter from boreal river. Freshwat. Biol., 23 : 301-309.

Trevors J.T. 1984. - The measurement of electron transport system activity in freshwater sediment. Wat. Res., 18 : 581-584.

Urbanc-Bercic O. 1997. — Reed stands in constructed wetlands : «edge effect» and photochemical efficiency of PS II in common reed. Wat. Sci. Tech., 35/5 : 143-147.

Wetzel R.G. 1981. — Limnologia. Ediciones Omega. Barcelona. 679 p.

Wetzel R.G. 1990. — Land-water interfaces : metabolic and limnological regulators. Verh. Internat. Verein. Theor. Angew. Limnol., $24: 6-24$. 